\title{
The Struggle of Traditional Religious Education in West Africa: The Case of Mahdara in Mauritania
}

\author{
Benaouda Bensaid ${ }^{1}$ \\ Istanbul Sabahattin Zaim University, Istanbul Turkey \\ Tarek Ladjal ${ }^{2}$ \\ Effat University, Jeddah, Kingdom of Saudi Arabia
}

\begin{abstract}
Over the course of time, the desert-based mahdara seminaries have made fundamental contributions to the preservation of the religious, spiritual, and cultural identity in West African societies. As an age-old nomadic entity, it was able to maintain a leading role in the promotion of socio-cultural traditions, as well as provide an indigenous model for public religious education in Mauritania. Following the country's independence and Mauritania's emergence as a nation state, modernity and political reform threatened and weakened the mahdara's prestige and glory. National educational reforms, globalization, weather crises and ensuing mass urbanization, in addition to ongoing political debates on the mahdara's model of instruction and its role in citizenship building, all had a role to play in its fate. The intense debate around the mahdara's reform continues to sharpen the divide between proponents of traditional religious learning, modernists, and proclaimed moderates. This paper explores the nature of the mahdara's struggle and the challenges shaping its position in the current religious, educational and political landscape, and leading to the adaptation and accommodation required for its survival. This study concludes that similar to other traditional institutions of Muslim learning, the survival of the mahdara in the face of insurmountable internal and external challenges and in view of its ambitions for progressive reform, the mahdara continues to celebrate itself as a unique model of religious learning whilst demonstrating an established core identity and reputation. Further research should highlight the interaction between tradition and modernity as seen in the case of the mahdara's survival and the necessity of the preservation of such endangered historical institutions of national and cultural identity.
\end{abstract}

Keywords: Mahdara, Mauritania education, Islamic education, Religious reform.

\section{Introduction}

As an age-old institution of Islamic religious learning in Mauritania, the mahdara represents an educational model that is complex yet represents an interesting phenomenon within the context of global religious education and cultures. Mauritania is home to a large number of Qur'an schools, particularly in cities like Nouakchott and Nouadhibou (Ballet, Bhukhuth \& Hamzetta, 2012). Those schools primarily focus on students' memorization of the Qur'an, which as Kobo noted, is seen as an intellectual achievement that defines social and intellectual status within the community (Kobo, 2016). The mahdara carries with it numerous meanings and implications, including those of populism, nomadism (bedouinism), independence, free public education, voluntary intellectual practice (Akpa, 2018; Nahwi, 1987), and serves to provide numerous functions in education, community engagement, spiritual and cultural preservation.

Mahdaras are supervised by dedicated religious scholars [shaykhs] who undertake the responsibility of the students' academic and moral development (Sufi, 1986). Emerging in the desert, the mahdara effectively adapted its functions, lifestyle, educational systems, social operations, and overall intellectual makeup in order to better suit the local life conditions of the desert, whilst effectively sustaining its role and presence dating back to the Moravids period (Ladjal \& Bensaid, 2017). However, despite the country's struggling economy and the student's poor financial conditions, the mahdara was still able to establish itself as an appealing destination for many foreign students hailing from Europe, the Americas and throughout the Muslim World, most of whom were attracted to the simple lifestyle, rigorous learning, and authentic methodology of instruction.

Interestingly, graduates of mahdaras today continue to make noteworthy contributions to reforms in religious education. At Al-Azhar University, for example, Taha Hussein noted that the Arabic language instruction only saw an improvement in quality following the appointment of mahdara graduate Mohammed

1 Corresponding Author: B, Bensaid, Faculty of Islamic Sciences, Istanbul Sabahattin Zaim University, Istanbul Turkey. Email: bbensaid@gmail.com

${ }^{2}$ General Education, Effat University, Jeddah, Kingdom of Saudi Arabia. Email: tarekladjal@gmail.com 
Walad al-Talamid al-Chinguetti (Hussein, 1990) as supervisor of the Arabic language program and curricula review (Rida, 1902). Ibn al-Talamid is also reported to have produced an index for Arabic manuscripts at ElEscorial Library as per the delegation of the Ottoman Sultan in 1886 (Ma' al-'Aynayn, 1984). Shaykh Ahmad ibn al-Amin al-Chinguiti was another mahdara graduate who made significant contribution to the review of Islamic studies and jurisprudence curriculums at Al-Azhar (al-Qalqami, 2009). Today, both Muhammad Hassan Walid al-Dido and 'Abdallah ibn Bayyah occupy positions of leadership at the European Council for Fatwa and Research.

Despite its academic rigour however, the mahdara continues to confront a series of postcolonial impediments, impasses of tradition and modernity, globalization, and the pressing challenge of addressing intense political debates on the reform of its method and instruction. Despite its resistance to impositions of a colonial past and barrages of attempts to eliminate, assimilate and adapt, the mahdara was unable to preserve its historical leadership position. Instead, the period following national independence and subsequent developments in the country's trajectory in modern education resulting from the emergence of a newly founded modern nation state altered the fate of mahdara schooling for much time to come.

The current decline in conditions of the mahdara continues to draw an increase in attention and regard from religious leaders, academics, and politicians. However, despite its significance and pivotal role in religious, educational and cultural development, the mahdara remains poorly studied at both the national and regional levels, and is nearly absent from official reports and national considerations. Traditional Qur'anic schools appear as an important vector for knowledge transmission in impoverished rural areas, and while it is a central issue for most sub-Saharan African countries, the quantification and qualification of the particular opting for an ArabIslamic education is poorly documented (d'Aiglepierre \& Bauer, 2018). Reports by Mauritania's Ministry of Education, such as those in 1996, 2004 and 2008, submitted to the $45^{\text {th }}, 47^{\text {th }}$ and $48^{\text {th }}$ Sessions of the International Conference on Education in Geneva, dismissed the mahdara's position and contributions altogether. Likewise, a 1999 report of the Ministry of Education's titled 'Education for All', 'the Situation of Primary Education' in 2002, 'Education of Youth and Vocational Training' in 2008, 'The Tripartite Report of the Ministries of Economy and Education, and 'The State of Education' in 2010; all appear to have deliberately dismissed any references to the role or contribution of the mahdara to education.

The mahdara is also absent from both the World Bank Report of 2000 on the state of education in Mauritania, a 2010 report by UNESCO, and is overall largely overlooked in academic research. This is critical given what Newman describes as the tendency amongst many international scholars of education and policymakers in evaluating Islamic education according to their exclusionary definitions and standards, and to engage with the sector only insofar as it is perceived to help deliver objectives, such as the Millennium Development Goals (MDGs) (Marshall, 2010). Faith institutions play vital yet complex and often under-appreciated roles in global education in that they offer particular advantages in meeting the pivotal challenges of education for marginalised groups and conflict-ridden societies. However, poor data and controversy around public and private roles in education can contribute to religion's exclusion from many influential debates (Marshall, 2010).

The current literature on the mahdara consists mainly of press articles and online blogs authored by Mauritanians who provide descriptive content on the history, development, education system, and conditions of the mahdara (Ladjal \& Bensaid, 2017). This is despite what Kobo (2016) described as the difficult for many today, especially in the West, to conceptualize the mahdara schooling system outside stereotyped negative perceptions. Research that directly addressed the mahdara issue include "Colonizing the Mahdara: Language, Identity, and Power in Mauritania under French Control" which, addresses the political struggle of the mahdara (Pettigrew, 2007) and "Desert-Based Muslim Religious Education: Mahdara as a Model" which discussed the religious model of mahdara with a special emphasis on its history, functions and teaching styles and with no discussions around its prospects or future (Ladjal \& Bensaid, 2017).

\section{Problems and Challenges Ahead of the Mahdara}

Despite its historical role and contributions to the shaping and preservation of the religious, educational, spiritual tradition and socio-cultural make-up of Mauritania, the mahdara appears to have largely failed to preserve its original status into the post-independence era because of several factors including postindependence policies, demographic transformations, radicalism, and reforms in education. In the following segment, we discuss the ways and means according to which those factors have affected the current condition of the mahdara. Those are by no means exclusive factors of influence, which have contributed to the evolving history of the mahdaras and their subsequent positioning today. 


\section{a) Mauritania's Post-independence policies:}

Throughout the history of Mauritania, the mahdara played a vital role in the shaping, preservation and promotion of religious identity, the Arabic language, traditional religious learning and culture. During the French colonial era however, the unwavering resistance of the mahdara defied abusive French policies and laws which sought to subjugate the mahdara institution to their administration as was evident in the 1903 law which both outlawed the establishment of new mahdaras and established a monitoring committee to restrict the enrolment of students in mahdaras so as to effectively redirect them to French schools instead. Throughout Africa, the transformation of Muslim schooling from the traditional Qur'anic pedagogy to a new system often described as "madrasa" commenced with the colonial period, especially in Muslim majority societies and in order to channel Muslims' intellectual energy towards colonial service (Kobo, 2016).

Under colonial rule, Muslims in West Africa resisted western-style education primarily provided by Christian missionaries. Suspicious of the colonialists' broader agenda, the majority of Muslim parents persisted in their rejection of secular education despite the acknowledgement that such schools had inevitably become sources of social and economic empowerment (Kobo, 2016). Despite those policies, French authorities failed to drive students to new secular schools, and as a result, issued a new law in 1906 in order to contain and control the mahdara altogether. This law for instance, granted monthly payments to mahdaras leaders, this however was soon discontinued due to the mahdaras' relentless resistance (De Chassey, 1977; Tarman \& Dev, 2018).

Lecourtois (1978), Dubie and others highlighted the role of mahdaras in the preservation of Muslims' religious and cultural identity as well as their resistance against French expansionism in West Africa (Bin Muhammadhn, 1996). Lecourtois also speaks of the mahdara instructors' campaigns [Shaykhs] against French schools and the issuance of religious verdicts ( $f a t w a$ ) in prohibiting the enrolment of Muslims in French schools (De Chassey, 1977). The impact of those verdicts was serious. In 1932, the total number of students enrolled in seven French schools was approximated at 438, this meant that only $1.1 \%$ of schoolgoing children were in attendance at French schools. The prestigious positions of the mahdara shaykhs also guaranteed influence on regional politics as was witnessed in 1860 where their role was instrumental in the deliberate failing of the General Staff of the French Army, H. Vincent, representative of General Faidherebe's mission to the Adrar region in which he sought to pave the way ahead of further French military intervention (Vincent, 1860). Those shaykhs also led revolts of local tribes against the French in 1860 and 1892, and continued their political and cultural struggle up until Mauritania's independence in 1960.

The independence newly defined, the relationships governing the state and its citizens as well as the state schooling system and the citizens who had at one point boycotted French schools in view of their destructive and colonizing culture. However, with the departure of the French and the establishment of the nation state (Izid Biyah, 2001), the state education system began to impose itself on even larger sectors and jurisdictions of the mahdaras, thus causing an increased rate of students dropping out of mahdaras. Prior to independence, the mahdara student population was estimated at an approximate $80 \%$, that however saw a sharp decline and student populations are presently estimated at $28 \%$. A 1977 survey indicated that $97 \%$ of schoolteachers were mahdara graduates (Lecourtois, 1978). This situation however has witnessed drastic changes as graduates of the mahdara have dropped to a further 17\% of the education sector's total teaching staff (Al-Nada, 1987).

Following independence, government sectors of media, law, public administration, and military recorded a visible presence of Mahdara graduates (Al-Nada, 1987). Soon however, with the newer graduates of the education system, the government commenced in questioning of the mahdara graduates' credentials; especially given that the mahdara does not grant its students formal certification (RAMS, 1981). Al-Nahwi noted that in the capital of Nouakchott, mahadara educators often found poor job prospects and no better than those of clerks or janitors since public service required official certification and proficiency in a foreign language (Nahwi, 1987). Those young people, produced by an Arabised education system and without any real employment qualifications, struggled to find employment, many of whom completed their secondary education in religious schools, while others emigrated to Gulf countries for the purpose of advancing their studies (Brichs, Etherington, \& Feliu, 2017). This condition however is no different than that of the French colonials under which mahdara scholars were at times regarded and even classified as illiterate regardless of their extensive scholarship or memorization of religious books (Nahwi, 1987).

To resolve this dilemma graduates were assisted with enrolling into the public education system in order to allow for their potential roles in the judiciary and government sector. This was achieved through generous support provided by the Kingdom of Saudi Arabia, which established an association for post-graduate studies and research in order to grant graduates having accumulated four years of study university degree equivalent certificates. Middle Eastern countries supported the sub-Saharan countries in various ways such as sending teachers to Arabic schools, training of local teachers with external support, and the provision of textbooks. The government also established an administration office at the Ministry of Islamic Affairs tasked 
with overseeing mahdaras and 'indigenous education' as well as regulating their annual financial support (Ould Abdel Wedoud, 2010).

Commencing from the mid-1980s, the challenge of poor economies in various West African countries forced governments to implement budget cuts in social services and education. It was at this point that madrasas became an alternative educational institution for impoverished Muslim children (Kobo, 2016). Given the poor economic status of Mauritania, mahdara instructors (shaykhs) were granted an annual stipend of less than 3000 MRO (equal to 15\$) which later saw an increase to 15000 MRO (50\$). Some mahdaras were entitled slightly higher pay as is the case of Shaykh Bdah Wald al-Bousayri's central mahdara who as the first appointed GrandMufti of Mauritania, was entitled to an annual 150000 MRO (600\$) A total annual funding of 100 million MRO allocated to these religious schools (Ould Abdel Wedoud, 2010) which was insignificant when compared with funds allocated to other official schools (Ould Ahmedou, 1997).

The government policies issued for mahdaras can best be described as haphazard. This is mostly due to the insufficiency of administrative bodies, poor management, a lacking of institutions, and isolation from the rest of the world. This was worsened by a political system characterised by authoritarianism in which political changes were largely the result of military intervention (Brichs et al., 2017). One such example includes the instance in which the government failed to identify student geographical distributions and the actual enrolment of students in mahdaras (Ould Ahmedou, 1997). The lack and even an unavailability of approximate statistics posed real challenges for researchers. In August 2012 however, the Ministry of the Islamic Affairs launched its first official census for mahdaras and mosques (Ould Idoumou, 2012). Figures published by the Department of Religious Affairs included data gathered on all mahdaras and Qur'an memorization circles throughout Mauritanian villages. According to statements of then Minister Ahmed Ould Neini, there existed an approximate of 6718 Mahdaras and 5082 Qur'an schools in Mauritania with a student population totalling at 163921 (Ould Abdel Wedoud, 2010). The 1995 census indicated the operation of 1728 mahdaras and approximately 88920 students (Ould Izid Bih, 2009). Those figures, however, failed to highlight specialized mahdaras, which according to most estimates, have sharply declined within the short period of only a few decades. Shaykh Mohammed al-Hassan al-Dado, founder of the Centre for Scientists Formation, noted that following the independence, dozens of specialized high-level mahdaras were decreased to a mere total of six including Mahdara of al-Adoud, al-Nabaghiya, al-Taysser, Hajj Ahmed Fahfo, and Badah Wald Bousayri.

\section{b) Demographic transformations:}

The social life, culture and traditional learning in Mauritania have long been interwoven with nomadism. The rural and desert social life was largely shaped by the very norms of the Mahdara. Hence, the mahdara and nomads enjoyed mutual acquaintances and benefits. Rural life benefited from the dissemination of knowledge and through the promotion of literacy amongst Mauritanians while the desert's communities gained advantage from both the financial and social support generously extended to the mahdaras. The latter largely depended on the mahdaras instructor's (shaykhs) assets which generally consisted of cows and camels which were used to attend to the various needs of attending students (Ould Izid Bih, 2009). Lecourtois draws attention to the example of Shaykh Ahmed Yazeed bin Hyani who sponsored one hundred students of his own mahdara (1978). With an increase in students however, new students were required to get along as their share of food contribution a cow or camel (Lecourtois, 1978). The latter would benefit the category of students known in the mahdara as destitutes ' $m u$ 'abbadun' who, were unable to secure funds or financial support. The countryside life appears to have directly influenced the shaykh's choice of cows instead of camels as payment for student enrolment fees, this was perhaps to ease their handling and availability of milk (Nahwi, 1987, p.142). In mahdaras, students would customarily take turns in feeding and caring for the cows and camels (Nahwi, 1987, p. 147). Others would feed animals while holding their slates (wooden pads) as others would await their turn.

Students in mahdaras are generally divided into groups known as the 'rahila' which compromise of four students who would share their stipends and food, on occasion, a fifth veteran or ' $m u$ ' $a b b a d$ ' student may be allowed to join (Al-Nada, 1987). In the case when the number of veteran students would increase to the extent of which the mahdara was unable to provide sustenance, residents of nearby villages would assist in the duty and provide nourishment on a daily basis (Ould Ahmedou, 1997). Interestingly, the harsh nature of the countryside appears to have contributed to strong ties of solidarity amongst the community and the mahdara as showcased through the provision of financial grants and awards, which generally consist of sheep gifted on the occasion of local marriages; sheep or goat loins; camel neck; wheat brought by caravans passing by mahdara; special meals prepared by community members on the occasion of students' memorization of a collection or book; gifts of appreciation for students on the occasion of having memorized the Qur'an brought by visitors and neighbours; donations known as 'jam ' al-khitma' collected by students having completed a fourth of the Quran's memorization; donations of papers and pencils from nomad families residing near the mahdara; clothing for 
students sown by local women; and when the cattle belonging to the mahdara did not return early, students would recite a special night call for neighbouring families to send some milk (Al-Nada, 1987). In terms of the Qur'anic school's social organization, students took part in the teacher's household until their graduation; there they offered services, which included assistance in farming and daily chores in exchange for their education (Kobo, 2016). Students' enrolment in mahdara also involves begging which is viewed as an expression of their commitment and discipline. According to Ballet, the conception of begging as a part of social life is readily accepted in West Africa, since in most West African countries' beggars were not socially excluded but rather occupy a central position in existing social structures (Ballet, Bhukhuth \& Hamzetta, 1995; Dube \& Cias, 2019; Kagema, 2018).

Nevertheless, such a favourable bond between the community and the mahdara was severely affected because of a series of transformations affecting the Mauritanian society after independence. An influx in the migration of nomads to urban populated centres resulted in dramatic alterations to the socio-cultural structures of the Bedouin society and Mauritania in general; this in turn impacted the stability of mahdaras which had relied on this base of social support and which prompted its decline. For instance, within a period of five years following independence, the population of nomads sharply declined from 64\% in 1965 to $32 \%$ in 1977 (MGPHC, 1977). Statistics collected in 2011 revealed that $41.5 \%$ of the population was urban with a yearly urbanization rate of $2.91 \%$ (CIA World Factbook, 2011), which rose to 3.2\% in 2015 (CIA, 2015), while the number of nomads sharply decreased from 128392 in 2000 to 66328 in 2013 (MGPHC, 2013). In a period of ten years, forty villages were established (MGPHC, 2013). As evidence of such rapid yet drastic transformation, one should note that Nouakchott, the capital city of Mauritania, which was established in 1957, doubled in population due to nomad migration caused by droughts (Taine-Cheikh, 2007) and saw a rise from 5807 city dwellers in 1962 to 590.532 in 1988 (Ould Cheikh, 2006) and later to 881.000 in 2009 (NTG, 2013). In 2013, the population of Nouakchott was estimated at about 958.000 , making up to $27 \%$ of Mauritania's total population (MGPHC, 2013).

Droughts represented a major factor in these transformative demographic trends. According to the World Health Organization (WHO), the last two decades of drought in Mauritania have caused profound demographic transformations to the country, which is made up of $90 \%$ desert terrain. The nomad population has rapidly declined, with people settling in rural areas and city shantytowns where access to clean water and sanitation is scarce (WHO, 2013).

From the 1970s up until the 1990s, widespread desertification severely affected Mauritania, and as a result, affected nomad lives and stability, rural economy and livestock. This further caused the transformation of communities, which were closely tied into the serious decline of conditions which had once allowed for the flourishing and primary role of mahdaras. The drought conditions continued to worsen in the years to come and it is estimated that the rate of rainfall fell in to $80 \% 2014$ when compared with rainfall in 2013. This was especially true in the Southern, Eastern and Central regions, pushing food security organizations to warn of serious consequences affecting pastoral and agricultural activity (Asnib, 2014). According to the government census, Mauritania is one of the most arid and vulnerable countries to desertification due to its location in the northern front of the coastal region. Studies confirm that the extent of desertification and land degradation in Mauritania amounted to more than $78 \%$. The Ministry of Environment confirmed the forests and other woodlands, which provide an average $80 \%$ of Mauritania's household energy needs, and livestock pastures currently, represent only about $3.3 \%$ of the country's landscape in light of the increasing rates of desertification (Asnib, 2015).

Desertification drove Mauritanians from nomad areas to cities in search of life security (Lecourtois, 1978). One such evident result of this phenomenon is the decrease of pastures and cattle, which caused mahdaras to lose vital resources. In 1969, the total number of cows in Mauritania was estimated at 2,400,000, which within a period of six years only, decreased to half of that number, and continued to decline to 1,120,000 in 1996, and later to less than half a million in 2000 (The State of Food and Agriculture-FAO, 2006). As a result of damaged agriculture, there was significant rise of poverty, which further exacerbated the situation of mahdaras which by now were no longer on the receiving end of donations or endowments. Families grew unable to enrol their children in the mahdaras, as they lacked the means and resources to provide them either with food or transportation. The eventual result was a sharp decline in student enrolment which posed a serious threat to the very existence of mahdara. Amjad Ould Sidati, a Mahdara instructor, believed that most rural areas or schools, in which he has studied or taught, suffered from serious problems that jeopardized the continuity of education. Sometimes, instruction would have ceased to continue had it not been for the efforts of generous parents who fundraised to ensure that schools survive (Zedni, 2016).

Such a rapid socio-economic transformation in the Mauritanian life shows the increasing decline of interest in the desert and nomadic life, this is in addition to city life also largely affecting general public life. For 
example, the intellectual passion, which existed amongst nomads, was also affected, and hence, there emerged instead stronger interest in financial profit, given that mahdaras no longer guaranteed their graduates decent employment. In this context, the rise of economic interests rose visibly where some mahdara Shaykhs became primarily concerned with collecting funds and donations; hence, emerged mahdaras mainly dedicated soliciting funds even in the case incompetent mahdara sheikhs (Albasheer, 2017).

\section{c) The Challenge of terrorism}

This situation of international terrorism, extremism and security presented an enormous political and socio-economic challenge for many African countries and organizations already burdened with trying to cope with longstanding and other newly arising security threats (Emerson \& Solomon, 2018; Tolba, 2018). The AlQaeda in the Islamic Maghreb (AQIM) operates across borders in the region of North and West Africa, this was particularly advantageous in Mauritania's vast geography and highly porous borders, which provided which $\mathrm{AQIM}$ and its partners a room for operation and further caused the government's task of control to grow in difficulty (Hussein \& Usman, 2018).

Following the outbreak of the Algerian political crisis in 1990, the West and Sub-Saharan Africa attracted many extreme Islamic ideologies and movements, which utilized the fragile political systems, power vacuum, and historical colonial sensitivities as a prime incubator. As part of the region, Mauritania paid the cost of violence and instability. In 1994 for instance, Mauritanian authorities captured a terrorist cell affiliated with the salafist jihadi movement. With the emergence of Al-Qaeda in the Maghreb, however, many of its leaders were Mauritanians, whilst others assumed roles of actual leaders including mahdara graduates such as Abu Yahya al-Libi, Abu Basir al-Libi, al-Bashir, Abu Sayyaf, Ali Ghali, Ali Medalj, Christos K. Aseerubas, Maxime Hochard (Abu al-Maali, 2015).

The rapid spread of extremist ideologies led to levelling accusations against the mahdaras. Walad Mohammed al-Basheer believe that mahdaras were the source of extremism and that its students were unable to adapt to modern change, and were thus alienated from society due to their ideological views of the ignorance of the large community and assumptions of exclusive piety within their close circles. The reason purported was that traditional textbooks used in the mahdara do not provide students proper access to learning about other cultures or universal human values, this he adds to the claim that his own mahdara, was not supportive of world peace, the principle of coexistence amongst religions, and instead based its teaching in constructs leading to extremism. His main contention was that mahdaras have evolved into hubs for violent radicalism as witnessed in Mauritania during the last fifteen years (Albasheer, 2017). Another prominent shaykh, now the master of the Adhwa' al-Bayan mahdara, Shaykh M. Lemine Ould Mann, explains the need for restructuring mahdaras in view of intervening external Muslim extremists in Mauritania, and their success in recruiting followers from among mahdara students and graduates, and even more detrimentally, their venturing in the establishment of their own mahdaras. Mann argued that the modernizing of mahdaras would help resolve the on-going battle between moderation and extremism in the Muslim world as a whole (Ould Abdel Wedoud, 2010).

In contrast, Mohamed M. Ould Abu al-Maali (2015), an expert on armed jihadi groups in the Greater Sahara cautioned against blaming extremism on Mahdaras leaders, but rather emphasized the desert's isolationist nature, in which both the state control and official institutions were mostly absent. This is in addition to the poor political experience of school leaders [shaykhs], which caused mahdara to turn into fertile hubs for those accused of terrorism in neighbouring countries who happened to also be interested in religious knowledge. This favourite isolation of mahdaras drew the attention of extremists who in the absence of instructors' awareness, started propagating his ideas among other students. As a result, radical discourse was disseminated into various mahdaras via pamphlets and tapes. However, following the failure to effectively propagate their extremist ideologies, most 'extreme foreigners' left the mahdaras and labelled its shaykhs as infidels. Abu alMaali argued that mahdara leaders were in actuality the ones who persuaded many extremists including a large number of extremist prisoners to abandon their ideas within the state-sponsored legal review program.

The intense debate over the positioning of mahdara leaders and the escalation of the counter-terrorism global discourse places mahdaras in a direct clash with political elites and Islamists. In the midst of this clash, the mahdara was considered as the favourable cradle for political Islam. Such a divisive tension could be traced back to President Muawyei Walad al-Tayei's term in which he sought to besiege political Islam in Mauritanian political and cultural life, along with his attempts of rapprochement with Western countries, and Israel in particular (Al-Arabi Jadid, 2016). This situation intensified bold accusations against mahdaras, especially those managed by parties of the political opposition. According to Mauritania's Prime Minister, Yahya Ould Hadami, the spread of al-Qaeda and some extremist elements in the South and West of the Mauritania was mainly due to the space they were given, where they learnt the fundamentals of radicalism and a strict interpretation of religion through unlicensed religious schools and doctrines, such as the mahdara. For him, Mauritania would be the first 
and most important reservoir in financing terrorist organizations by producing ideological fighters to practice terrorism (Arab newspaper, 2016). Such sceptic relations between the mahdara and radicalism has only added to vilification of the mahdara. Opponents of the mahdara used this condition as grounds for increased marginalization of mahdara while proponents used it to claim that there exist political agendas manipulating all sorts of terrorist accusations against the mahdara.

\section{Reform of the Mahdara}

The socio-cultural changes in Mauritania sped up modernization and thus placed the mahdara before existential threats, and forced it into the course of accommodating modern developments including the undertaking of revising its fundamental characteristics (Lecourtois, 1978). This challenge caused intense debates amid mahdara scholars and other intellectuals. Two groups can thus be identified, the first being Mauritanian modernists and reformists who advocated for the development and modernization of the mahdaras whilst criticizing the old styles of instruction. Shaykh M. al-Mahdi Ould M. Albacheer, who is described as a modernist, highlighted the need for developing mahdara to rescue it from alienation due to the gap between the traditional knowledge students had acquired and the very reality they lived in (Ould Abdel Wedoud, 2011). For Albacheer, the mahdara curriculum should replace old styles of instruction to the incorporate modern sciences and technology. He based his argument on the legislative codes of mahdara scholars on Mauritanian criminal law in which they advocated the punishment of uncovered or 'improperly' dressed women as well as texts advocating the imposition of taxes on Christians and Jews (jizya) (Wald China, 2013). For him there is a need for change in the rules in regulating mahdaras and the necessary criminalizing of violent teachers (Ballet et al., 2012).

The call for modernization can be seen through notable mahdaras like that of Tayseer established by Shaykh Mouloud Ould A. el Gawad (d. 1828). His mahdara embarked in modernization since its establishment in 1973 and operates a private publishing house (Moukhtar, 2012). Abu Mohammed Ould Mohamed al-Hassan, son of the current Mahdara Shaykh, speaks of programs and initiatives incorporating digitalization and online instruction, especially for those students living abroad. The Tayseer offers online classes via Skype to students from around the world (Moukhtar, 2012). Likewise, the efforts of Mohammed al-Hassan al-Dado are noteworthy In Nouakchott, al-Dado established the Centre for Scholars' Formation. This large establishment is equipped with study halls, a library, specialized teachers, and fifty-two branches of Islamic education. This highlights the clear shift from nomadic styles of instruction to modern ones.

Another group includes conservatives and traditionalists, who opposed calls for modernization. Their point is that the true advantage of the mahdara lies in the simplicity of its nomadic (bedouin) lifestyle and the traditional nature of its curricula and frames. One such advocate is Adah Wald Sidati, shaykh of a mahdara in West Mauritania, who confidently speaks of the mahdara's ability to preserve its instruction methodologies, despite the widespread availability of technology and its remaining intactness despite pressing changes. In his view, the student's use of wood for light and fuel contains blessings and such blessing are found greatly in traditional methods (Wald China, 2013). His inherent argument is that graduates of the mahdara are more competent than those hailing from renowned universities such as Al-Azhar or Zaytuna (Wald China, 2013).

In light of this debate, and with growing global political and media attention to religious the education system and its placement in relation to discourses of extremism, Mauritania's government undertook a restructuring of mahdaras and attempted to recuperate the country's public image whilst avoiding any political turmoil that plagued Mauritania since the fall of Ould Taya. This led to the government's establishment of a database on all mahdaras in order to better ensure their management, support, control, and to identify their official leadership, educational standards, grades and rates of foreign students (Asnib, 2015). In 2016, the government introduced new legislations and restrictions to regulate the flow of foreign students in mahdaras, and who according to statistics of the Ministry of Islamic Affairs in 2012, made up a quarter of the total population of mahdara students population (163,912) ("Mauritania: Ministry of Religious Affairs," 2012). In January 2017, the government decreed the closure of several Qur'an schools in implementing its new regulations; one such affected school included the prominent Warsh Institute. The government also conducted an evaluation of the Nouakchott Institute for the Formation of Scholars in search for potential legal violations. UNICEF also launched the first talibé awareness-raising campaign in 1992 to enable shaykhs to formally register their schools in the case they were willing to teach subjects matters other than the Qur'an, and if they agreed to give up using corporal punishment and sending the children out to beg (Ballet et al., 1995). 
The Ministry of Islamic Affairs in Mauritania also cooperated with the United Nations Children's Fund (UNICEF) to organize the Nouakchott International Seminar in 2011 in an effort to review ways to modernise mahdaras and to integrate them into the country's education system (Umar, 2011), international experts and supervisors of religious education across Mauritania attended this seminar. The seminar's final deliberations included granting semi-official certificates to mahdara graduates in order to help build bridges with modern education and address the need to introduce mechanisms for the development of mahdara curricula and review its teaching methodologies (Umar, 2011). In collaboration with the Islamic Bank (IDB) and the Islamic Educational, Scientific and Cultural Organization (ISESCO), the Ministry of Islamic Affairs launched an initiative in June 2015 to conduct in-depth studies and programs to simultaneously develop and modernize mahdara curricula for its integration into the modern schooling system. The initiative attempted to export the experience of the mahdara to sub-Saharan Africa as a mechanism to combat poverty, the Islamic Development Bank further allocated funding for this project's follow up. Three ideal mahdaras were selected as study samples for follow-up and future dissemination. This was however, all set according to standards that consistent with the objectives of ISESCO and the Ministry of Islamic Affairs, which would enable mahdaras to play new educational roles within Mauritania's education system (Asnib, 2015; Griffen, 2018).

Here it is worth noting that government policies and measures failed to satisfy observers and mahdara advocates. For example, Shaykh Ould Abidine views the measures taken by the Ministry of Islamic Affairs and Education as an imposed guardianship over religious institutions in Mauritania seeking to minimize their impact on the political scene. He also accused the Ministry of failing to activate the Directorate of Mahdaras and Indigenous Education, initially arranged to support and rescue mahdaras, which for him, stood as evidence of the officially intended marginalization of the mahdara and lack of genuine support for the rehabilitation of mahdaras in official bodies. Others interpreted those steps as a political move to undermine the strong political opposition party like the Islamic National Rally for Reform and Development (INRR), to which most of Mahdara officials belonged (Bakhir, 2016).

\section{Conclusion}

In spite of the numerous contributions the mahdara has made in the formation and preservation of the religious, traditional and spiritual identity of the nation, its catalytic role in the engagement of rural communities, educational impact on successive generations, and resistance against colonial deracination of Muslim religious learning, the changes following Mauritanian independence appear to have affected its core functions. The emergence of Mauritania as a nation state in combination with poor economic conditions, increased rates of urbanization and migration to cities, the effects of modern education and technology in rewarding economic incentives affected family choices and deeply affected mahdara student enrolment. On the margins of an increasingly capitalistic system, the mahdara became a victimized scapegoat of escalating extremism and labelled as a breeding ground for terrorism.

Consequentially, the mahdara increasingly became the centre of various heated political debates addressing calls for modernized education, the preservation of tradition and heritage, combatting violent and exclusivist ideologies, religious discourses in citizenship building, or the power and influence of traditional religious scholars. The continuous focus on the mahdara only demonstrates its powerful visible and structural presence in the country's matters of religion, education and identity building. In light of its integral role in Mauritanian traditional and cultural heritage, authorities have resolved to invest in its reform, development and in support of public education, especially considering its powerful potential for providing sound educational opportunities in remote rural and marginalized communities.

Despite its encountering of countless hurdles, the mahdara must overcome, it will continue to play various positive roles in the context of West African educational reforms. Doing so requires amendments to instruction methods and approaches, the integration of strategies and modern education, as well as step away from wooden tablets in order to prepare students for the realities of a more complex and dynamic world than those of the shaykh's tents. In light of this, it is important to note that although wrestling with the exigencies of modernity and development takes many forms and shapes, it should not undercut the need for freedom, cultural diversity, and celebration of indigenous histories, cultures and traditions. Instead of the mahdara being the critical subject for a rigid evaluation of modernity, and the censuring of its role altogether, one ought to consider its history, contributions and persisting attraction to a large Western student poll in approaching it as a serious partner in education, culture, and community building. Such a perspective would not only preserve and enrich the extant reformation of the mahdara, but would also prompt exploration into the meaning of modern education reform. 


\section{References}

Akpan, L. (2018). The political undertone in the development of nomadic education in Africa: Lessons from Nigeria. American Journal of Qualitative Research, 2(1), 1-21.

Al-Arabi Jadid. (2016, January 5) Koranic Schools in Mauritania, Do you pay the bill of political conflict between the Muslim Brotherhood and the regime, Al-Arabi Jadid Newspaper. Retrieved from http://www.huffpostarabi.com/2016/01/05/story_n_8914862.html

Albasheer, W. M. (2017, October 29). Terrorism cannot be eliminated before changing the curricula of the Mahdara. Aqlam. Retrieved from http://aqlame.com/article3116.html

Al-Nada, M. M. (1987). Dawr Al-Mahadir fi Mauritani. Institute of Islamic Studies.

al-Qalqami, A. 'A. B. (2009). A 'lam al-Shanaqitah fi al-ijazwa-al-Mashriq. Riyad: Dar al-Nashr al-Duwali lilNashr wa-al-Tawzi'.

Arab Newspaper. (2016, January 11). The Koranic schools in Mauritania are laboratories for the breeding of jihadists in West Africa, Al-Arab newspaper. Retrieved from http://www.alarab.co.uk/?id=70386

Asnib, S. (2014, December 31). Desertification increases in Mauritania as rain shortage continues, Arabia Channel. (2015, June 30). National Plan to Develop the Mahdara in Mauritania, Al-Arabiya news.(2015, June 18). Desertification consumes $78 \%$ of the territory of Mauritania, Arabia Channel.

Bakhir, S. (2016). The Closure of Koranic schools causes widespread debate in Mauritania. Journal of alMujtama'.

Ballet, J., Bhukuth, A., Hamzetta, B. (2012). Vulnerability to violence of "Talibe" children in Mauritania. Child Abuse \& Neglect: The International Journal, 36(7-8), 602-607.(2019). The Exploitation of Talibé Children in Mauritania. Child Exploitation in the Global South. Cham: Palgrave Macmillan.

Bin Muhammadhn, M. (1996). Mauritanian Mahdara: The mobile nomadic university. Journal of Islamic History, 7(2), 49-71.

Brichs, F. I., Etherington, J., \& Feliu, L. (Eds.). (2017). Political Islam in a Time of Revolt. New York, NY: Springer.

Central Intelligence Agency. (2015). Mauritania. The World Factbook. Government Printing Office. Retrieved on 26 Nov 2017.

De Chassey, F. 1977. La Mauritanie 1900-1975. L'Etrier: la Houe et le Livre Ed. Paris: Anthropos.

D‘Aiglepierre, R., \& Bauer, A. (2018). The choice of Arab-Islamic education in sub-Saharan Africa: Findings from a comparative study. International Journal of Educational Development, 62, 47-61.

Dube, B , Cias, T . (2019). State-based curriculum making in a post colonial Zimbabwe: Making sense of Family, Religious and Moral Education in a global context. Journal of Social Studies Education Research, 10 (1), 241-258. Retrieved from http://dergipark.org.tr/jsser/issue/45447/570412

Emerson, S., \& Solomon, H. (2018). Terrorism and extremism. African Security in the Twenty-first Century. doi: $10.7765 / 9781526122742.00010$

Griffen, A. J. (2018). Enacting African American Legislative Voice: A Program Design for the Recruitment and Development of African American Educational Lobbyists. American Journal of Qualitative Research, 2(2), 74-102.

Hussein, M. D., \& Usman, A. R. (2018). Terrorism: A Challenge for Africa's security and development in the 21st Century. Journal of Health and Social Issues, 7(2), 85-93.

Hussein, T. (1990). al-Ayyam. Cairo: Dar al-Ma'arif.

Izid Biyah Mahmud. (2001). Al-Zawaya fi Bilad Shinqii fi muwajahat al-isti 'mar al-Faransi. Nouakchott: National Publication House.

Kagema, J. (2018). The School Curriculum and Its Influence on Teacher Motivation in Curriculum Implementation in Kenya. Journal of Culture and Values in Education, 1(1), 9-25. Retrieved from http://cultureandvalues.org/index.php/JCV/article/view/3

Kobo, O. M. (2016). Paths to progress: Madrasa education and Sub-Saharan Muslims' pursuit of socioeconomic development. In H. Tiliouine \& R. J. Estes (Eds.), The State of Social Progress of Islamic Societies (pp. 159-166, 175). Switzerland: Springer International Publishing.

Ladjal, T., \& Bensaid, B. (2017). Desert-Based Muslim Religious Education: Mahdara as a Model. Religious Education, 112(5), 529-541.

Lecourtois, A. (1978). Etude expérimentale sur l'enseignement Islamique traditionnel. Rapport final de l'expert. Montrouge, Paris: SEMA Entreprises et développement.

Ma' al-'Aynayn wuld M Al-Amin. (1984). Ibn Al-Talamid Al-Shanqiti, his life and his legacy. MA Theses, University of Tripoli.

Marshall, K. (2010). Education for all: Where does religion come in? Comparative Education, (46)3, 273-287, doi:10.1080/03050068.2010.503739 
Mauritanian General Population and Housing Census. (1977). National Office of Statistics, Mauritania. (2013). National Office of Statistics, Mauritania.

Mauritania: Ministry of Religious Affairs prepares comprehensive survey of mosques and mahdaras. (2012 August 22). Retrieved from https://www.saharamedias.net/

Mohammad, M. Abul Maali. (2015 May 15). Foreign Students in Mauritanian Mahdaras: Eligible for jihad or secret migration? Retrieved from http://kiffainfo.net/article10183.html

Moukhtar, S. (2012, August 14). Mahdara of Taiseer: Three Century of Scientific Giving. Al-Khaleej Newspaper. Retrieved from http://www.alkhaleej.ae/supplements/page/9fe20348-e65c-4814-a220$9 \mathrm{~b} 3644 \mathrm{~d} 468 \mathrm{~d} 8$

Nahwi, K. (1987). Bilad Shinqit al-manarah wal-ribat. Rabat: Arab League Educational, Cultural, and Scientific Organization. Nouakchott Travel Guide. Retrieved from http://www.world66.com/africa/mauritania/nouakchott on 25 November, 2017.

Newman, A. (2018). Islamic education in Africa: Writing boards and blackboards. Compare: A Journal of Comparative and International Education, 1-3. doi:10.1080/03057925.2018.1543156.

Ould Abdel Wedoud, M. Y. (2010, October 28). Mauritania counters extremism with education. Magharebia Newspaper. (2011, September 23). Islamic scholar links religious schools and radical ideology. Magharebia Newpaper.

Ould Abu, M. (2017, November 29). Foreign students in Mauritanian courts: Candidates for jihad and secret immigration. Dune-voices news. from http://dune-voices.info/public/index.php/ar.

Ould Ahmedou, E. G. (1997). Enseignement traditionnel en Mauritanie-La Mahadra ou l'école, à dos de chameau. Paris: Harmattan.

Ould Cheikh, A. W. (2006). Nouakchott, capitale nomade? D. Retaillé, La ville ou l'État, 87-100.

Ould Idoumou, R. (2012, September 10). Mauritania to impose mosque oversight. Magharebia Newspaper.

Ould Izid Bih, E. B. et al. (2009). L'enseignement coranique traditionnel dans les Mahadras de Nouakchott: Etats des lieux et perspectives. Réseau Ouest et Centre Africain de Recherche en Education, Mauritania, 12, 25

Pettigrew, E. (2007). Colonizing the Mahadra: Language, identity, and power in Mauritania under French control. Ufahamu: A Journal of African Studies, 33(2-3).

RAMS Project. (1981). Rural assessment and manpower surveys (Mauritania). (Non-Formal Education). http://pdf.usaid.gov/pdf_docs/PNAAM237.pdf

Rida, M. R. (1902). Ibn al-Talamid, Jikni. Journal of al-Manar, 4(4).

Sufi, M. (1986). The Mauritanian Mahdaras and its educational implications on the Mauritanian society. (pp. 24). (Master Thesis). University of Imam Saud, USA.

Taine-Cheikh, C. (2007). The (r) urbanization of Mauritania: Historical context and contemporary developments. In C. Miller, E.Al-Wer, D. Caubet, \& J.C.E. Watson (Eds.). Arabic in the City (pp. 4968). Routledge.

Tarman, B., \& Dev, S. (2018). Editorial: Learning Transformation through Innovation and Sustainability in Educational Practices. Research In Social Sciences And Technology, 3(1), i-ii. Retrieved from http://ressat.org/index.php/ressat/article/view/363

Tolba, N. (2018). From Rebellion to Riots. Research In Social Sciences And Technology, 3(2), 93-114. Retrieved from http://ressat.org/index.php/ressat/article/view/358

Umar, J. (2011, September 30). Mauritania aims to reform Mahdara education. Magharebia Newspaper.

Vincent, H. (1860). Voyage et expédition au Sénégal et dans les contrées voisines. Voyages dans l'Adrar et retour Saint-Louis.

Wald China, M. (2013). Modernity conquers Mauritanian Mahdaras. Journal of Al-Mujtama', Kuwait.

World Health Organization. (2013). Environmental health challenges in Mauritania, Retrieved from http://www.who.int/features/2013/mauritania_environmental_health/en/

Zedni Network. (2016, September 28). Mahdaras of countryside in Mauritania: Koranic schools in the open, Zedni Network for Education. Retrieved from http://zedni.com/ Retrieved on 22/09/2017 